\title{
Small and medium-sized accommodation managers and opportunities for water conservation
}

\author{
Albert Llausàs* Josep Padullés Cubino** Anna Ribas Palom***
}

Universitat de Girona (España)

\begin{abstract}
To improve the environmental performance of small and medium-sized accommodation enterprises, it is important to understand the factors and motivations that move managers to adopt more efficient technologies and ecologically responsible practices. A sample of 18 independent family-run hotels and campsites were contacted in the mature tourist resort area of the Costa Brava (Spain). The research worked with a combination of surveys and semi-structured interviews directed at top managers. Saving water is revealed as a matter figuring low on the list of priorities of most managers, while competitive advantages and stakeholder pressures appear as less relevant drivers than is posited in most of the scientific literature. We conclude that addressing organizational factors holds more promise in terms of transformative power supporting water conservation than structural or technological changes.
\end{abstract}

Keywords: Corporate Environmental Responsibility; Environmental Management; Manager perception; Sustainable Tourism; Water Conservation.

Pequeños y medianos gestores de alojamientos y oportunidades para la conservación del agua

Resumen: A fin de lograr una mejora de la gestión ambiental de las pequeñas y medianas empresas de alojamiento es importante comprender los factores y motivaciones que impulsan a sus gestores a adoptar tecnologías más eficientes y prácticas ecológicamente responsables. Una muestra de 18 hoteles y campings en la destinación turística madura de la Costa Brava (España), todos ellos gestionados por empresas familiares independientes, fueron contactados para el proyecto. La investigación se basó en la combinación de encuestas y entrevistas semi-estructuradas con los máximos responsables de los establecimientos. El ahorro de agua se revela como una cuestión de baja prioridad para la mayoría de gestores, mientras que las ventajas competitivas y la competencia por el uso de agua por parte de otros grupos sociales aparecen como factores menos relevantes que en la mayor parte de la literatura científica publicada. Se concluye que incidir sobre los factores organizativos tiene un mayor potencial de transformación de las empresas para el ahorro hídrico que no los cambios que puedan realizarse a nivel estructural o tecnológico.

Palabras Clave: Responsabilidad Ambiental Corporativa; Gestión Ambiental; Percepción; Turismo Sostenible; Ahorro Hídrico.

\section{Introduction}

At the global scale, water consumption by the tourism sector is small when compared with other sectors, such as agriculture and industry (Gössling, Hall, \& Scott, 2015; Kirk, 1995). However, at the local scale and during specific seasons, the relationship between tourism and water use can be complex and may have important implications for sustainable resource use. Although the water consumption of a single tourism accommodation enterprise can be insignificant, collectively, the cumulative demand of such enterprises can represent between $10 \%$ and $20 \%$ of the national domestic water use in countries in which tourism is a key sector of the economy (Gössling et al., 2012).

\footnotetext{
* Universitat de Guirona; E-mail: albert.llausas@udg.edu

** Universitat de Girona; E-mail: josep.padulles@udg.edu

*** Universitat de Girona; E-mail: anna.ribas@udg.edu
} 
Such is the case in Spain, where tourism accounts for $10.9 \%$ of the GDP, employs $11.9 \%$ of the workforce, and is responsible for approximately $12 \%$ of domestic water consumption (Gössling et al., 2012; Instituto Nacional de Estadística, 2013). The importance of good water management in regions such as the Costa Brava is also emphasized by the negative effect of past episodes of water scarcity on the touristic images of other Spanish regions, such as Benidorm, Mallorca or Barcelona (Gil Olcina, 2010; March, 2015; Wheeler, 1995). The likelihood of water crises in Mediterranean mass-tourism destinations such as these is expected to increase in the future in response to climate change, an increasing number of visitors, and the higher water intensity of visitor activities (Gössling et al., 2012; Kent, Newnham, \& Essex, 2002). Despite the predictions and the urgency of action, many authors have identified a relative lack of research on the relationship between tourism and water use (Deyà Tortella \& Tirado, 2011; Hadjikakou, Chenoweth, \& Miller, 2013). Water-tourism interactions, impacts and opportunities have often been overlooked in the scientific literature and within the sector.

In certain areas of the Spanish Mediterranean coast, such as Mallorca, the accommodation offerings are dominated by international chains, which often operate massive resorts and own thousands of beds (Deyà Tortella \& Tirado, 2011). However, in other regions, the hospitality sector primarily consists of a large number of smaller operations, often family-run, which authors such as Garay and Font (2012) group under the label SMAE (small and medium-sized accommodation enterprises). In fact, Bohdanowicz (2006, p. 664) notes that 70\% of European hotels are independently owned and managed. The accommodation sector in Catalonia accurately reflects these circumstances, with most enterprises belonging to the SMAE group, the vast majority of which fall into the category of micro-enterprise with 10 or fewer employees (Garay \& Font, 2012).

Despite the pivotal role of SMAEs in the environmental effect of touristic activities in many destinations, several authors have noted the scarcity of research on such enterprises (Garay \& Font, 2012; Kasim, 2009). This scarcity might be explained at least in part by the difficulty of studying a sample that is highly fragmented among many small owners, who often lack systematic records of their activities and are unlikely to possess a formal environmental policy (Bohdanowicz, 2006; Kasim, 2009). These limitations make directly approaching the SMAE managers the best option to investigate the actions that they undertake, the opportunities and barriers that they encounter, and the factors that motivate their decisions (Chan, 2011; Kasim, 2009; Park, Jeong Kim, \& McCleary, 2014)

The first objective of the research presented in this article was to assess the level of proactivity of a sample of SMAEs characteristic of a mature Mediterranean tourism destination with respect to the implementation of water-saving policies and measures on their premises. Second, we wanted to identify the organizational factors that influence the action/inaction of the sampled hotels and campsites in support of water conservation, including the perceptions and motivations of the managers. The third objective was to recognize opportunities and barriers to improving water management in Costa Brava SMAEs on the single-business scale, at the local level, or on the regional or national scale.

\section{Literature Review}

In an influential article on the motivations and factors that influence corporate ecological responsiveness, Bansal and Roth (2000) developed a framework that groups such motivations and factors into three categories: competitiveness, legitimation and ecological responsibility. Tri-partite classification frameworks with highly similar categories have been proposed by Ayuso (2006) and Garay and Font (2012) in their studies on the adoption of responsible social practices in the accommodation sector.

\subsection{Competitiveness}

The literature assessing motivations in the tourism industry to adopt greener practices, including water conservation, frequently identifies cost reductions as main drivers - if not the most important driver - with respect to innovation (Bohdanowicz, 2006; Carmona-Moreno, Céspedes-Lorente, \& De Burgos-Jiménez, 2004; Céspedes-Lorente, de Burgos-Jiménez, \& Álvarez-Gil, 2003; Charara, Cashman, Bonnell, \& Gehr, 2011; Claver-Cortés, Molina-Azorín, Pereira-Moliner, \& López-Gamero, 2007; Dinarès \& Saurí, 2015).

A second source of competitive advantage that may derive from the adoption of water-saving innovations in the sector is the possibility of achieving a favourable corporate image and product differentiation (Miles \& Covin, 2000). Hotels and campsites may benefit from this strategy because it enhances their capacity to attract new guests (Chan \& Wong, 2006; Kirk, 1995), increases the satisfaction of current 
guests and therefore the probability of repeat visits (Lee, Hsu, Han, \& Kim, 2010; Millar, Mayer, \& Baloglu, 2012), makes guests more likely to join in their efforts (Chan \& Wong, 2006; Lee et al., 2010), and improves their relationship with the local community (Kirk, 1995; Nicolau, 2008; Wei \& Ruys, 1999).

\subsection{Legitimation}

Companies can legitimize their activities by complying with government regulations and adequately responding to pressures from a variety of other stakeholders who are affected by the activity of these companies (Bansal \& Roth, 2000). Thus, institutional and stakeholder theory have often been used as a suitable framework to examine the range of motivations that stimulate the adoption of environmental management systems and other practices in the hospitality sector (Ayuso, 2006; Céspedes-Lorente et al., 2003; Rivera, 2004).

Abundant evidence confirms that environmental regulations generally have a positive effect in prompting companies to incorporate sustainability criteria into their operations (Chan \& Wong, 2006). However, there are indications that the regulatory framework is not at the forefront of the concerns of firms in relation to water use and conservation (Styles, Schoenberger, \& Galvez-Martos, 2015). In Spain, environmental regulations do not incentivize innovation in the hotel sector, as Claver-Cortés et al. (2007) and Molina-Azorín et al. (2009) argue. In addition, Charara et al. (2011), Cole (2014), Dinarès and Saurí (2015) as well as Kelly and Williams (2007) attribute water-use regulation failures to enforcement, power struggles and compliance issues in regions as diverse as Barbados, Bali, Spain and Canada.

\subsection{Ecological Responsibility}

Top managers have long been recognized to play a key role in the implementation of environmental policies and practices in the lodgement sector (Kirk, 1995). This statement is particularly true for small independent hotels, in which the personal ethics of the owners may be directly translated into practice (Sampaio, Thomas, \& Font, 2012; Tzschentke, Kirk, \& Lynch, 2008). For example, Ayuso (2006) concludes that organizational change in chain-affiliated hotels was better achieved when environmental practices were determined by the managing directors themselves than when imposed by the hotel chain. Park et al. (2014) demonstrate how the cognitive bases, concerns and values of managers influence environmental strategic decisions in U.S. hotels. Garay and Font (2012) find three altruistic reasons (i.e., environmental protection, lifestyle, social commitment) as the main motivations for hotel managers in Mallorca to engage in sustainability practices, ahead of economic and legitimation drivers.

\section{Study Area}

The study area includes the neighbouring municipalities of Pals $\left(25.8 \mathrm{~km}^{2}\right)$ and Torroella de Montgrí-l'Estartit $(65.9$ km²), both located on the Costa Brava's Bay of Pals (Baix Empordà: 42.017842 N, 3.189937 E). The final stretch of the Ter River, which flows between the towns, and the adjacent coastal areas are included in the Natural Park of Montgrí, Illes Medes and Baix Ter.

The traditional rural landscape, with its iconic paddy fields, has been altered over the last 50 years by new urban developments (e.g., first- and second-home residential areas, hotels, camping resorts) and sport and recreational facilities, such as golf courses associated with the tourism boom. The total population in 2015 was approximately 14,000 . However, this number increases to over 22,000 in summer due to a seasonal influx of visitors from other regions of Spain and Europe, particularly France and Germany (Idescat - Statistical Institute of Catalonia, 2016). The area is known as a mature tourist destination of international fame.

The climate is typically Mediterranean with an average annual temperature and precipitation of $14.8^{\circ} \mathrm{C}$ and $333 \mathrm{~mm}$, respectively. Periods of drought are common in the summer and occasionally linger for months, which results in severe water stress. For example, the drought of 2007 and 2008 was the worst in Catalonia in the previous 68 years. Additionally, the frequency and magnitude of droughts are forecast to increase in the region as a consequence of climate change (Ribas, Calbó, Llausàs, \& Lopez-Bustins, 2010).

Currently, water is primarily supplied by conventional hydrologic resources, such as canals that transport water from the Ter River and groundwater from wells (Gabarda-Mallorquí \& Ribas Palom, 2016). Water supply is a municipal service in Spain and provided in the local area by the Consorci de 
la Costa Brava, a consortium that serves 22 municipalities. Over the last decade, the economic crisis and parallel steep water-price increases have contributed to progressively decrease per-capita water consumption in Catalonia (Gabarda-Mallorquí \& Ribas Palom, 2016).

\section{Methods}

Qualitative approaches are particularly well suited to investigating the relationship between SMAEs and their environmental policy and performance (Ayuso, 2006; Charara et al., 2011; Erdogan \& Baris, 2007; Kasim, 2009). In contrast to quantitative methods based on systematic surveys, the flexibility of open, semi-structured interviews enables researchers to adapt the focus of their study to fit the singularities and complexity of each sampled case (Connell \& Lowe, 1997). This property makes qualitative research more sensitive to micro-management decisions and personal stories, perceptions, attitudes and behaviours, which have been demonstrated to be critical in determining action by small-scale companies (Ayuso, 2006; Chan, 2011; Park et al., 2014; Razumova, Ibáñez, \& Palmer, 2015). In addition, interviews and follow-up questions may enable researchers to uncover determinants and drivers that have an influence on manager decisions but which might be omitted in other types of pre-designed assessment (Kasim, 2009; Le, Hollenhorst, Harris, McLaughlin, \& Shook, 2006; Martin \& Woodside, 2008).

\subsection{Data Collection and Processing}

An exhaustive search through tourism internet portals and fieldwork resulted in the identification of 37 hotels and camping resorts in the study area. Only these two types of tourist accommodation were included in the study because they alone represent over $99 \%$ of the total overnight stays (Idescat - Statistical Institute of Catalonia, 2016). To secure a broad sample, an invitation to participate in the study was delivered one week before we contacted all businesses by telephone. To reach additional owners, we used a snowball sampling method among those owners who directly agreed to participate in the study. Simultaneously, to more widely publicize the study, we contacted the Union of Employers of Hospitality and Tourism of the Costa Brava Centre (Unió d'Empresaris d'Hostaleria $i$ Turisme de la Costa Brava Centre), an association of 450 companies in the hospitality and tourism sector. As a result, a total of 18 accommodation establishments (6 camping resorts and 12 hotels) agreed to participate.

The interview consisted of 19 open-ended and 10 closed-ended questions (see full interview in the Appendix I). It was specifically designed to obtain information regarding business characteristics and owner feedback on 6 issues: (i) water consumption by the tourism sector of the Costa Brava, (ii) the water management model in the establishment, (iii) the application of water-saving measures and actions, (iv) the prospective implementation of water-saving measures, (v) assessment of water-saving measures and (vi) water-management policy.

All interviews were conducted by a team of four researchers on the premises of each establishment with the owner or the top manager between May and November 2015. The average time per survey was approximately 35 minutes. The results of the closed-ended questions, which facilitate a characterization of each business, were entered into a spreadsheet. All interviews were anonymised, and the answers to the 19 open-ended questions were fully transcribed verbatim. Of the 18 interviews, 17 were conducted in Catalan and one in Spanish.

\subsection{Data Analysis}

The qualitative analysis of the transcribed interviews relied on the grounded-theory methods first presented by Glaser and Strauss (1967) and developed by Corbin and Strauss (1990), implemented with the support of computer-assisted qualitative data analysis software (CAQDAS). The goal of grounded theory is to provide an understanding of social settings by completing a sequence of stages (including data collection, theoretical sampling, iterative data coding, the generation of categories, writing memos) and, finally, interpreting the results to construct a new theory (Elliott \& Timulak, 2005; Neuman, 2005). Grounded theory and its variations have been successfully used in tourism and management studies (Connell \& Lowe, 1997; Hardy, 2005; Martin \& Woodside, 2008; Riley \& Love, 2000). However, fewer authors have applied it to examine sustainability issues in this sphere (see, for instance, Ayuso, 2006; Kensbock \& Jennings, 2011).

Grounded theory proposed an entirely inductive approach while consciously avoiding the influence of pre-existing theory and literature (Glaser \& Strauss, 1967). However, recently, the need to incorporate 
previous knowledge and to develop the method to increase the "theoretical sensitivity" (cf. Corbin \& Strauss, 1990) of the research has been recognized (Elliott \& Timulak, 2005). Therefore, grounded theory can be viewed as a set of tools for both the inductive and the deductive analysis of empirical material (Charmaz, 2006). Our application of the method used both properties.

In a first stage, data coding was performed by a researcher with little familiarity with the literature. This approach resulted in a highly open system of codes, which facilitated the identification of innovative emerging themes and the formulation of new theory after an inductive process based on constant comparison. However, a thorough review of the literature on the relationship of hospitality management with water use and broader sustainability issues provided the backbone of an axial coding hierarchy, thus facilitating a parallel deductive and explanatory analysis of the findings (Corbin \& Strauss, 1990). Specifically, at a higher level, two main codes were dedicated to "stakeholders" and "interactions". Within the former, separate sub-codes were created for "managers", "staff", "administration" and "customers". The level of development within each of these codes varied, with sub-codes within the "managers" category further classified into two new hierarchical levels ("competitive advantage" and "perceptions/ awareness") and a total of 14 sub-codes in the deepest fourth level. The "interactions" code, involving two stakeholders or more, was further divided into three sub-categories ("regulatory framework", "association/knowledge exchange", "corporate social responsibility"), each of them containing between 3 and 6 sub-codes. Iterative reading of transcribed interviews and segments facilitated the quantification of instances, the identification of patterns and the connection of discourses with the scientific literature.

Excerpts from the interviews translated into English by the authors are presented in the following section to illustrate several findings. After anonymization, all of the names that appear are fictional.

\section{Results}

\subsection{Characterization of the sampled SMAEs and their Water Conservation Proactivity}

The 12 hotels and 6 camping resorts in the study area that were investigated represent $49.6 \%$ of the total number of tourism accommodation businesses. Identifying attributes of these establishments, such as the legal category or the type of tourism among its clientele, is crucial to understanding their environmental management practices (Álvarez Gil, Burgos Jiménez, \& Céspedes Lorente, 2001). In this regard, heterogeneity emerged among enterprise characteristics (Table 1).

All firms were family-owned businesses and fit the definition of an SMAE. Half of the firms began operation between 1950 and 1970 during the first tourism boom, and only two were established between 1990 and 2010. The category of the hotels ranged from 2 to 4 stars. No clear relationship between the class/category of the establishments and the number of available beds could be observed in our data. However, smaller businesses ( $<50$ beds in hotels and $<1000$ units in camping resorts) typically had longer opening seasons. International tourists were the most regular customers, particularly at the camping resorts although the presence of national visitors was also notable at seven hotels. Diving tourism, notable at two hotels, also plays an important role in the area because remarkable marine reserves, such as the Medes Islands, can be most conveniently reached from the study area.

The most common water source for SMAEs was the public network although two camping resorts and four hotels used other sources, such as their own wells or rainwater tanks. Fifteen and 14 establishments had a pool and a laundry, respectively, whereas only six offered a spa. As expected, the area of vegetated surface was substantially larger at camping resorts, where $6,000 \mathrm{~m}^{2}$ were green on average. Higher-rated hotels also had larger vegetated areas on their properties (Table 1).

The managers were questioned regarding water-saving measures (WSMs) adopted by their businesses between 2000 and 2015. In this regard, camping resorts appeared to be more active. Half had applied more than 10 different measures or strategies to save water. In contrast, half of the hotels, particularly the hotels in the third category ( 2 stars), had applied six or fewer. The most frequently encountered WSMs applied during this period were delivering information to customers to increase awareness (16 sites); awareness-raising among employees (14); the installation of aerators, sensors or timers on taps and showers (13); the installation of double-flush flow cisterns (12) and the use of more efficient filtration systems to clean the water in swimming pools (11). Other measures, such as grey-water reuse (2), the collection and reuse of rainwater (3) or paving outdoor surfaces (3), had been scarcely implemented. 
Table 1: Basic features of the sampled hotels and camping resorts.

\begin{tabular}{|c|c|c|c|c|c|c|c|c|c|c|}
\hline Category $^{1}$ & $\begin{array}{l}\text { Decade of } \\
\text { opening }\end{array}$ & Guest capacity & Seasonality & $\begin{array}{c}\text { Customer } \\
\text { profile }^{2}\end{array}$ & $\begin{array}{l}\text { Water } \\
\text { source }\end{array}$ & Pool & Spa & Laundry & \begin{tabular}{c|} 
Area of \\
vegetated \\
surface $(\mathrm{m} 2)$
\end{tabular} & \begin{tabular}{|c} 
Application of \\
WSMs (2000- \\
$-2015)^{3}$ \\
\end{tabular} \\
\hline \multicolumn{11}{|c|}{ Camping resorts } \\
\hline 1 & 1981-1990 & $<1000$ & All year & Int & Net & Yes & No & Yes & 4100 & $* *$ \\
\hline 2 & $1961-1970$ & $<1000$ & April-October & Int & $\begin{array}{l}\text { Net/ } \\
\text { Well }\end{array}$ & Yes & No & Yes & 1800 & $* * *$ \\
\hline 1 & $1971-1980$ & $\geq 2500$ & May-September & Int & Net & Yes & No & Yes & 13300 & $* * *$ \\
\hline 1 & $1951-1960$ & $\geq 1000 \&<2500$ & April-September & Int & Net & Yes & Yes & Yes & 4500 & $* *$ \\
\hline 1 & $1961-1970$ & $\geq 1000 \&<2500$ & May-September & Int & Well & Yes & No & Yes & 3500 & $* *$ \\
\hline 1 & $1961-1970$ & $\geq 2500$ & May-September & Int & $\begin{array}{l}\text { Well/ } \\
\text { Reg./ } \\
\text { Cha. }\end{array}$ & Yes & No & Yes & 9800 & $* * *$ \\
\hline \multicolumn{11}{|l|}{ Hotels } \\
\hline 3 & $1961-1970$ & $<50$ & $\begin{array}{l}\text { February- } \\
\text {-November }\end{array}$ & Int/Nat & Net & No & No & No & 0 & * \\
\hline 3 & $1951-1960$ & $\geq 150$ & April-November & Div & Net & No & No & Yes & 0 & * \\
\hline 2 & $1961-1970$ & $\geq 50 \&<150$ & $\begin{array}{l}\text { February- } \\
\text {-December }\end{array}$ & Div & Net & Yes & No & Yes & 20 & $* *$ \\
\hline 2 & $1971-1980$ & $\geq 150$ & April-October & Int & Net & Yes & No & Yes & 30 & * \\
\hline 2 & $1961-1970$ & $\geq 150$ & March-December & Nat & Net & Yes & Yes & Yes & 300 & $* *$ \\
\hline 3 & 1971-1980 & $<50$ & July-September & Int/Nat & Net & No & No & No & 0 & * \\
\hline 1 & $1981-1990$ & $\geq 50 \&<150$ & All year & Int & $\begin{array}{l}\text { Net/ } \\
\text { Sea }\end{array}$ & Yes & Yes & Yes & 1000 & * \\
\hline 1 & $1991-2000$ & $\geq 150$ & April-November & Int/Nat & Net & Yes & No & No & 4000 & $* *$ \\
\hline 3 & 1961-1970 & $<50$ & All year & Int/Nat & $\begin{array}{l}\text { Net/ } \\
\text { Well }\end{array}$ & Yes & No & Yes & 4500 & * \\
\hline 1 & $1981-1990$ & $\geq 50 \&<150$ & March-November & Int/Nat & $\begin{array}{l}\text { Net/R. } \\
\text { Tank }\end{array}$ & Yes & Yes & Yes & 1200 & * \\
\hline 2 & $1971-1980$ & $<50$ & All year & Int/Nat & Net & Yes & Yes & Yes & 600 & $* *$ \\
\hline 1 & 2001-2010 & $\geq 50 \&<150$ & March-November & Int/Nat & $\begin{array}{l}\text { Net/ } \\
\text { Cha. }\end{array}$ & Yes & Yes & No & 8000 & $* * *$ \\
\hline
\end{tabular}

${ }^{1}$ Hotel category has been rescaled ( 4 stars $=1 ; 3$ stars $=2 ; 2$ stars $=3$ ).

${ }^{2}$ Int = primarily international family; Nat = mainly national family; Int/Nat = both international and national family; Div = Diving tourism.

${ }^{3} \mathrm{WSMs}=$ water-saving measures. ${ }^{* * *}=$ Adoption of more than $10 \mathrm{WSMs} ;{ }^{* *}=$ Adoption of more than 6 but fewer than 10 WSMs; * = Adoption of 6 or fewer WSMs.

\subsection{Organizational Determinants of Water Conservation Action and Inaction}

Following Bansal and Roth's framework (2000) presented in the literature review, the organizational motivations and factors that influence corporate ecological responsiveness where grouped into three main categories: competitiveness, legitimation and ecological responsibility.

\section{- Competitiveness}

In the sample, there is evidence of factors related to economic competitiveness that triggered changes in the facilities or management of hotels and campsites. For example, cost savings were cited 5 times in the interviews, often to justify the measures adopted by campsites to reduce the volume of drinking water they use, such as sourcing their own irrigation water from wells. Sanjay, the owner of a small but high-category hotel, extended his vision of an economic motivation to the entire sector:

"The hospitality establishment saves [water] because it has an invoice behind it. The issue of water would be of no importance otherwise. It [the hospitality establishment] doesn't understand the problems with water, the sources of water, how problematic it is to find water." 
However, for each statement that cites cost reduction as the primary reason to adopt water-saving devices and practices, there were at least two statements that coupled economic factors with reasons of a different nature or disregarded such factors as the main reason for action. Waylon, a campsite manager, witnessed a transition within his industry:

"By what we see in the meetings of camping-resort managers, it [water conservation] is a topic that is brought to debate. Initially, it was a purely economic matter, but it's increasingly regarded as a matter of environmental concern."

If water conservation action were solely the result of economic motivations, it is unlikely that many initiatives would occur in the sector because the cost of water provision is relatively low, at least compared with other services. Certain managers, such as Seymour, openly acknowledged this fact, whereas many others did so implicitly:

"As a cost, water is not that relevant. We can afford to let it leak, to put it this way. So I think that in the end it's more a matter of awareness when we say: 'ok, even if this leak at the end of the month does not represent many euros, let's try to fix it so it stops leaking."'

Water use in the sampled SMAEs was found to be closely related to marketing, corporate image and product differentiation. However, the nature of this connection turned out to differ substantially from the one reported in the literature. Symptomatically, only the managers of two of the larger camping resorts and the manager of a small high-category rural hotel included marketing and image improvement in their discussion of water conservation. In one case, actions were justified by the desire to transmit an image of naturalness to the campsite's guests. In the second campsite case, the "sustainable consumption of water" was attributed to a "commercial strategy", and the hotel manager had rejected the installation of bathtubs in favour of showers to project an image of "modernity". In most cases, the interviews reflected a paradigm in which water must be abundant and the vegetation lush, both in the accommodation and in the surroundings, to transmit a positive image of the destination and thereby attract tourists:

"It is also important to acknowledge that the campsite sells nature, and therefore, the customer demands could foil water savings because you can't pave open areas." (Ralph)

"Cleanliness trumps consumption. Spending 1000 extra litres of water per day in exchange for the facilities to be clean is of no importance. Cleanliness trumps consumption." (Sanjay)

Asked how active hotels in the Costa Brava are in terms of water conservation, Carl, the owner of a hotel and golf course, presented a highly revealing view on the lack of urgency to address water-saving in the sector in relation to its return in terms of corporate image improvements. His view might also suggest that the use of new communication technologies by guests is perceived more as a threat that can punish poor management than an opportunity to project the environmental innovations of the business:

"Because we are in contact with other hotels and campsites, we see that considering investments to conserve water is left at the end of the list [of priorities] because these are things that the guest is not aware of. To implement measures that are not visible is hard within the priorities of a hotel. Now, with internet, the image is very important because the customer can criticize you."

\section{- Legitimation}

Among the sample of 18 SMAEs in the study area, not one interviewee explicitly identified regulatory pressures as a motivation to reduce water consumption. Instead, the interviewee comments focused on the abundance of norms that address water-quality issues and the confusing and excessive bureaucratic burden that regular operation requires. In certain cases, these norms were the alleged reasons that prevented businesses from adopting certain water-saving solutions.

"In the long term, I'm thinking of collecting rainwater to be able, for instance, to water the garden. It would be feasible, but the problem is that you cannot build a tank where there is water within a one-metre distance." (Maude) 
"For instance, for us to connect to the network, we need many permits, and the studies that you need to complete are very demanding. The real problem is the many administrations that have been progressively created. This area is within the range of a radio beacon in Begur, and if we want to do anything, we must also ask for permission from aviation authorities! All of this limits your operability." (Carl)

The relationship between the government and the tourism sector is more complex than regulation enactment and compliance, and the sampled managers recognize in the institutions a stakeholder with the potential to influence their actions and legitimation efforts in several other ways. In certain cases, it was perceived that with better coordination with the authorities, a more integrative vision, and an economic incentive the accommodation sector could contribute more to water-conservation efforts:

"I think that the government has many tools, but it seems that as long as water reaches the customer and it complies with the norm, it's enough for them. They don't say, "let's do a plan for three years to reduce water consumption"; the only thing they do is increase the bill." (Helen)

"Occasionally, we have the desire to do many things together [with the government], but something gets in the way and makes it difficult for us. So, we do things on our own." (Seymour)

Many interviewees agreed that the government has successfully raised awareness on water-scarcity issues in recent years. However, a number of individuals have demanded that these efforts be enhanced in the face of a climate change. From similar medium and long-term perspectives, a recurrent opinion was that a permanent solution was necessary to guarantee water provision to the Costa Brava based on the argument that under the current circumstances the provision of drinking water to the metropolitan area of Barcelona was favoured over local needs. In many cases, it was suggested that the solution would be the long-discussed water transfer from the Rhône river, in southern France. This widespread view reflects once more a dominant paradigm based on meeting current and future water demand by increasing available resources.

For the sampled hotels and campsites, the guest was not the primary motivation for managers to adopt water-saving measures although the guest's role was acknowledged. It was recognized that there is a high level of environmental awareness among European guests, which helps hotels and camping resorts implement water-saving strategies, such as only replacing towels on request. However, it was believed that European guests are increasingly stringent in terms of service provision and that it was occasionally difficult to influence their behaviour.

When explicitly questioned regarding the environmental-performance conditions that tour operators might have imposed in return for cooperation, none of the interviewees stated requirements regarding water-conservation standards.

\section{- Ecological Responsibility}

A high degree of environmental awareness could be identified in the discourse of at least eight interviewed hotel and campsite managers. However, it is difficult to solely attribute environmental action to personal ethics because in each of the eight cases an altruistic motivation appeared coupled with the realization that good environmental conditions were necessary for the attractiveness of the sector in the study area and in the everyday operation of each business. In addition, it is impossible to establish a clear correlation between the interviewees' stated degree of environmental awareness and the level of proactivity in adopting WSMs in their establishments.

Although many interviewees recognized the value of water to their activities, they would often admit that its conservation was perceived as a matter of low environmental concern in the region due to the natural availability of the resource or the strategic weight of the tourism sector in the event of water shortages:

"As a sector, we are not worried because we will normally find [water] in one place or another to get through the two or three summer months. We are not worried because it is expected that during those months the reservoirs will be used a bit more, and then the volume will be recovered from somewhere else." (Montgomery)

It is interesting to note the role that experience and memory may have played, consciously or unconsciously, in guiding actions at certain hotels and campsites. Although virtually all interviewees clearly remembered the intense drought during the summer of 2007, which came close to imposing restrictions 
on filling swimming pools, only the most experienced owners and managers of family-run establishments recalled previous occasions when water delivery was threatened and occasionally discontinued due to a combination of water scarcity and poor infrastructure. Two of these businesses were the only hotels in the sample that have added alternative water sources (i.e., a rainwater tank and a well) to the public network, and two other hotels with long histories chose to keep water tanks operative as a backup in case of emergency. These four hotels are among the most active adopters of WSMs.

\subsection{Barriers to and Opportunities for improving Water Management in SMAEs \\ - Barriers}

The 18 interviews confirmed that, firstly, the low cost of water and, secondly, the small proportion represented by water-related expenses within the overall budgets of the sampled hotels and campsites prevent managers from being more concerned regarding water conservation:

"Our business is based on seasonality. We are open for half a year but full occupation lasts only a month and a half. With what we earn during this time we have to pay workers, sustain the business during the winter and try to make some improvements to the establishment." (Edna)

A third disincentive to pay more attention to water issues cited by the interviewees was the monopolization of the water-provision service and infrastructure by a single concessionary and the lack of a market in which multiple water companies offer a range of competitive pricing schemes and alternatives:

"Electricity companies compete to get their electricity contracted and they even offer energy-saving studies to potential clients. That is not the case for water. They don't really care." (Ned)

Water has been shown not to be a priority for most interviewees, even in cases where a high environmental awareness was established. In addition, in certain cases where environmental concern was observed, it was clear that the interviewees did not base their views and decisions regarding action or inaction on accurate knowledge or extensive assessments of the issue. The oft-cited lack of perception of pressure from guests to introduce water-saving practices and technologies was another barrier to conservation initiatives in our case study.

The accommodation sector in the local study area presents particularities that might also be considered barriers to innovation in the field of water conservation. Most notably, a low level of competition was observed among most businesses, particularly the hotels. Finally, the dominance of a discourse that in most cases reflects an entrenched paradigm of prioritizing water supply at all costs over the moderation of water demand to reduce the environmental footprint of businesses can be viewed as a background barrier that also acts to prevent more determined and ambitious action.

\section{- Opportunities}

The most obvious advantage that was identified among the interviewees (in all but one case) was a keenness to improve the way in which they managed water, a circumstance that was occasionally made highly explicit:

"Honestly, there are many aspects [of management] that take preference over water, but it is obviously a matter that we take into account. The simple fact that we are having this interview is because we are interested in everything connected with this topic." (Waylon)

"I don't know [if we plan to implement water conservation measures in the mid to long term]. What could we do? Anything that would bring savings then... of course yes [we would like to implement it]." (Maggie)

Another opportunity stated by the manager of one of the businesses was to establish collaborative efforts to reap the benefits of economies of scale, for instance through the joint acquisition of technology:

"We will need to consider the idea of the collaborative economy. Rewarding or paying. It's necessary to reward those who make the effort so, for instance: if I have room for a water tank, but I don't have much irrigated area in the garden, maybe it's worthwhile if where it is possible to collect water, water is collected there, and wherever the right place to consume is, it is consumed there." (Seymour) 


\section{Discussion}

\subsection{Organizational Factors as Key Determinants of Water Conservation}

Our findings confirm that structural factors in the hospitality sector matter in determining the level of commitment to the adoption of water-saving strategies. At the broadest level, the higher total water use of campsites, due to extensive irrigated outdoor areas and the overall number of guests, might explain a higher level of involvement in the adoption of WSMs compared to hotels. However, within each type of accommodation, differences are much less clear, which indicates that organizational factors might be more influential in determining the activities of each SMAE.

All of these organizational factors emerged in our research at different points during the interviews, often validating the findings of other authors. However, in certain cases, our findings challenge or nuance the established wisdom. In addition, unprecedented factors have been identified that influence decisions.

Challenging observations by authors such as Bohdanowicz (2006), Chan \& Wong (2006), Charara et al. (2011), Dinarès \& Saurí (2015), Lee et al. (2010) or Millar et al. (2012), our results do not provide strong support for cost reductions or corporate image enhancements to be the main incentives driving business decisions to save water. This might be explained by external factors, such as the relatively low cost of water for the operation of accommodation establishments in the study area (with the result that the adopted measures require longer to amortize), and by internal factors, including the possibility that the subsequently examined motivations might have a stronger influence on management decisions. In fact, other studies in Spain have reported similar results, in which cost reductions were only relatively important for the adoption of more sustainable practices (Ayuso, 2006; Garay \& Font, 2012).

Most of the demands made by the 18 sampled SMAEs to the environmental authorities nearly exactly match the results obtained by Kasim (2009, p. 720) in 17 interviews with hotel managers in Kuala Lumpur, Malaysia. The important role of the government in more actively promoting water conservation has also been noted by other researchers, such as Charara et al. (2011), Deyà Tortella and Tirado (2011) and Dinarès and Saurí (2015).

For the sampled SMAEs, the guest was not the primary motivation for managers to adopt water-saving measures. In many tourism and business-management studies, the guest is identified as the most influential stakeholder in forcing the accommodation sector to adopt more environmentally friendly practices (Butler, 2008; Hillary, 2004). However, there is evidence that this is not always the case, particularly for smaller hotels (Hillary, 2004; Kasim, 2009; Revilla, Dodd, \& Hoover, 2001).

According to our results, there is no clear correlation between the interviewees' stated degree of environmental awareness and the level of proactivity in the adoption of WSMs in their establishments. This finding is consistent with several contributions that report a misalignment between stated environmental attitudes and behaviour in the hospitality sector (Charara et al., 2011; Erdogan \& Baris, 2007; Hillary, 2004; Le et al., 2006). Often, this misalignment is explained by a desire to appear socially responsible (Bohdanowicz, 2006). However, it has also been attributed to a shortage of capital and human resources (Razumova et al., 2015) or a lack of knowledge (Kasim, 2009; Mensah, 2006).

\subsection{Addressing Barriers to and Opportunities for Improving Water Management in SMAEs}

All respondents pointed out that the low cost of water and the small proportion water-related expenses represent within their overall budgets prevent managers from being more concerned about water conservation. This observation seems to apply not only to the study area. It has also been reported to deter managerial action in many other locations (Charara et al., 2011; Razumova et al., 2015; Styles et al., 2015). The regulatory framework, which appears to be relatively stringent in terms of water quality, provides little or no incentive for hospitality firms to act on quantity issues. In addition, SMAEs are specifically affected by certain of their characteristics. The literature commonly recognizes that smaller businesses do not have the same level of capital resources to face costly investments, and this factor was also observed for our sample. In fact, Garay and Font (2012) found that the primary reason why small and medium-sized Mallorca hotels do not undertake more sustainability practices was a lack of funds (76\%).

Another weakness commonly attributed to smaller firms is the low level of professionalization and the lack of staff specialized in environmental management (Hillary, 2004; Mensah, 2006). In the sample, only one manager, the director of a camping resort, was an appointed professional not related to the family that owned the company. This fact makes environmental action by hotels and campsites particularly reliant on the personal ethics, entrepreneurship and time availability of the owner-manager, as noted by Ayuso (2006), Park et al. (2014) and Razumova et al. (2015). 
In addition, in certain cases in which environmental concern was observed, it was clear that the interviewees did not base their views and decisions regarding action or inaction on accurate knowledge or extensive assessments of the issue (see also: Chan, 2011; Kasim, 2009; Mensah, 2006). In accordance with Charara et al. (2011), Erdogan and Baris (2007), Kasim (2009) and Mensah (2006), these circumstances might help explain the frequent lack of correlation between the discourse, which in most cases exhibited strong environmental awareness, and the actual level of commitment in terms of implemented or planned WSMs.

It should also be noted that that a low level of competition was observed among most businesses, particularly the hotels. These circumstances might make the competitive advantage of adopting more ambitious environmental practices that result in cost reductions or, in particular, public image improvements irrelevant for these hotels. This situation might be explained by several factors, including the reliance on a loyal clientele of central and northern European customers, scuba divers who wish to visit the unique underwater environment of the nearby Medes Islands, groups of retirees brought by governmental social programmes during the low season, and guests who purchase package vacations from professional tour operators who do not impose strict environmental conditions on accommodation enterprises. In addition to these factors that more or less guarantee a constant influx of visitors, the expansion of urban areas is severely limited by strong development restrictions and the presence of a natural park in many of the remaining open spaces. Thus, competition from new lodgements is not expected.

The most notable opportunity identified among interviewees was the keenness to improve the way in which they managed water. Our findings demonstrate that the dominant reactive approach to corporate social responsibility that was observed among most owners and managers, particularly hoteliers, must not be equated with a passive attitude towards environmental management and improvement. Rather, it means that if barriers are removed and conditions and stimuli that match the needs and demands of the SMAE profile are provided hotels and campsites are likely to respond.

Clearly, more and better strategies to disseminate information and transfer knowledge among SMAEs would easily increase environmental awareness and enable managers to make more informed decisions that consider the advantages of reducing their water footprint (Kensbock \& Jennings, 2011). Therefore, as many other authors prescribe, it would be advisable for businesses in the study area to create a platform or alliance that facilitates a degree of coordination and knowledge exchange among managers rather than relying on individual perceptions, experience, efforts, or the advice from equipment providers (Kasim, 2009; McLennan, Becken, \& Stinson, 2014; Mensah, 2006; Molina-Azorín et al., 2009; Park et al., 2014; Razumova et al., 2015). Of course, this type of organization would be a good forum in which to discuss broader environmental management matters in addition to water, facilitating an actual enhancement in the environmental culture of the businesses (Ayuso, 2006). The tendency for SMAEs to depend on a single individual to make decisions, which was described as a barrier in the previous subsection, could be viewed as an opportunity insofar as these owner-managers represent key stakeholders whom awareness and knowledge exchange programmes should preferentially target.

In addition to the described opportunities in the sphere of knowledge exchange, a collaborative effort might enable SMAEs to reap the benefits of economies of scale that larger businesses typically enjoy, for instance through the joint acquisition of technology. This approach might be particularly useful for a group of sampled hotels that are concentrated in a small area in the compact urban fabric of l'Estartit.

\subsection{Limitations}

Conducting and analysing interviews is an intense capital-, staff- and time-consuming activity that only yields relatively small samples. In our study, a relatively small number of subjects (18 SMAEs) were analysed, which might limit the generalization of our results outside the study area. In this regard, further research is required to validate the conclusions from our SMAEs in other tourist destinations.

In addition, it should be noted that the sample may be slightly biased in favour of establishments with a stronger commitment to environmental concerns and water conservation. This bias has commonly been observed in other empirical studies on the Spanish hospitality industry (Carmona-Moreno et al., 2004; Céspedes-Lorente et al., 2003; Dinarès \& Saurí, 2015). Moreover, a degree of non-response error, which occurs when a minimum response rate of $50 \%$ is not achieved, must also be assumed (Fowler Jr, 2013).

Another difficulty commonly reported in the scientific literature on hospitality derives from the importance of addressing the highest possible management level because it exerts the largest influence on strategic factors, including environmental responsibility (Ayuso, 2006; Kasim, 2009; Park et al., 
2014; Razumova et al., 2015). In respect of this, targeting a sample of SMAEs might have minimized this limitation but not completely avoided it.

\section{Conclusions}

The particular characteristics of the sampled SMAEs and the individual views and preferences of their owners and managers are of particular relevance in explaining the proactivity of the studied firms. In fact, many barriers were described that prevent or hinder a more active involvement of the sector in achieving water savings. These barriers include a relative lack of competition in the local area, the low level of professionalization, a stated environmental awareness that rarely translates into water conservation action or the adoption of formal policies and certificates, and the absence of organizations that facilitate knowledge exchange and the generation of economies of scale.

The main implication of our research is that environmental management improvements in SMAEs on the Costa Brava's Bay of Pals lie more in cultural advancement than in structural change. Structural factors, such as the size of a hotel or the facilities that a campsite offers, cannot realistically be expected to be changed in an effort to save water. Conversely, organizational factors, including aspects of business management and the personal motivations of managers, hold more promise in terms of transformative power. A combination of increased external pressure by public administration and/or the customer base and the promotion of internal initiatives could produce this change. For example, different pricing policies and water-use regulations have been cited as capable of providing the first ingredient, whereas a platform to foster knowledge exchange, cooperation, the joint acquisition of technology or coordinated training has been proposed in this paper to encourage initiatives from within the sector, in coordination with the government. The keenness of most of the interviewees to be more active indicates a substantial opportunity to facilitate such changes.

Future research should not only increase the attention it pays to smaller enterprises to understand the relationship of the hospitality sector with the environment but also should be more integrative with respect to the different dimensions of this relationship. In this sense, future research should strive to integrate the analysis of environmental attitudes, awareness and behaviour with the results of the undertaken actions. Our research and the wider literature indicate that large inconsistencies can exist between the stated level of environmental concern of accommodation managers, their actual degree of proactivity in promoting action and the environmental impact of the adopted measures. The recommendation of effective best practices in the sector can only stem from a transversal research effort. Based on our experience with a case study, a mixed methods approach can benefit from the advantages provided by quantitative and qualitative methods while minimizing the effects of sample bias and decontextualized correlations.

\section{References}

Álvarez Gil, M. J., Burgos Jiménez, J., \& Céspedes Lorente, J. J. 2001. An analysis of environmental management, organizational context and performance of Spanish hotels. Omega, 29(6), 457-471.

Ayuso, S. 2006. Adoption of voluntary environmental tools for sustainable tourism: analysing the experience of Spanish hotels. Corporate Social Responsibility and Environmental Management, 13(4), 207-220.

Bansal, P., \& Roth, K. 2000. Why Companies Go Green: A Model of Ecological Responsiveness. Academy of Management Journal, 43(4), 717-736.

Bohdanowicz, P. 2006. Environmental awareness and initiatives in the Swedish and Polish hotel industries-survey results. International Journal of Hospitality Management, 25(4), 662-682.

Butler, J. 2008. The compelling "hard case" for "green" hotel development. Cornell Hospitality Quarterly, $49(3), 234-244$.

Carmona-Moreno, E., Céspedes-Lorente, J., \& De Burgos-Jiménez, J. 2004. Environmental strategies in spanish hotels: contextual factors and performance. The Service Industries Journal, 24(3), 101-130.

Céspedes-Lorente, J., de Burgos-Jiménez, J., \& Álvarez-Gil, M. J. 2003. Stakeholders' environmental influence. An empirical analysis in the Spanish hotel industry. Scandinavian Journal of Management, 19(3), 333-358.

Chan, E. S. 2011. Implementing Environmental Management Systems in Small- and Medium-Sized Hotels: Obstacles. Journal of Hospitality \& Tourism Research, 35(1), 3-23. 
Chan, E. S., \& Wong, S. C. 2006. Motivations for ISO 14001 in the hotel industry. Tourism Management, 27(3), 481-492.

Charara, N., Cashman, A., Bonnell, R., \& Gehr, R. 2011. Water use efficiency in the hotel sector of Barbados. Journal of Sustainable Tourism, 19(2), 231-245.

Charmaz, K. 2006. Constructing grounded theory: A practical guide through qualitative analysis. Thousand Oaks, CA: SAGE Publications.

Claver-Cortés, E., Molina-Azorín, J. F., Pereira-Moliner, J., \& López-Gamero, M. D. 2007. Environmental Strategies and Their Impact on Hotel Performance. Journal of Sustainable Tourism, 15(6), 663-679.

Cole, S. 2014. Tourism and water: from stakeholders to rights holders, and what tourism businesses need to do. Journal of Sustainable Tourism, 22(1), 89-106.

Connell, J., \& Lowe, A. 1997. Generating grounded theory from qualitative data: the application of inductive methods in tourism and hospitality management research. Progress in Tourism and Hospitality Research, 3(2), 165-173.

Corbin, J., \& Strauss, A. 1990. Basics of qualitative research: Grounded theory procedures and techniques. Basics of Qualitative Research: Grounded Theory Procedures and Techniques, 41.

Deyà Tortella, B., \& Tirado, D. 2011. Hotel water consumption at a seasonal mass tourist destination. The case of the island of Mallorca. Journal of Environmental Management, 92(10), 2568-2579.

Dinarès, M., \& Saurí, D. 2015. Water consumption patterns of hotels and their response to droughts and public concerns regarding water conservation: The case of the Barcelona hotel industry during the 2007-2008 episode. Documents d'Anàlisi Geogràfica, 61(3), 623-649.

Elliott, R., \& Timulak, L. 2005. Descriptive and interpretive approaches to qualitative research. A Handbook of Research Methods for Clinical and Health Psychology, 147-159.

Erdogan, N., \& Baris, E. 2007. Environmental protection programs and conservation practices of hotels in Ankara, Turkey. Tourism Management, 28(2), 604-614.

Fowler Jr, F. J. 2013. Survey research methods. Thousand Oaks, CA: Sage publications.

Gabarda-Mallorquí, A., \& Ribas Palom, A. 2016. Understanding reductions in water consumption in tourist areas: a case study of the Costa Brava, Spain. International Journal of Water Resources Development, 1-19.

Garay, L., \& Font, X. 2012. Doing good to do well? Corporate social responsibility reasons, practices and impacts in small and medium accommodation enterprises. International Journal of Hospitality Management, 31(2), 329-337.

Gil Olcina, A. 2010. Optimización de recursos hídricos y armonización de sus usos: el Consorcio de Aguas de la Marina Baja. Investigaciones Geográficas, 51, 165-183.

Glaser, B. S., \& Strauss, A. 1967. The discovery of grounded theory. Chicago: Aldine Publishing Company. Gössling, S., Hall, C. M., \& Scott, D. 2015. Tourism and water (Vol. 2). Channel View Publications.

Gössling, S., Peeters, P., Hall, C. M., Ceron, J.-P., Dubois, G., Lehmann, L. V., \& Scott, D. 2012. Tourism and water use: Supply, demand, and security. An international review. Tourism Management, 33(1), 1-15.

Hadjikakou, M., Chenoweth, J., \& Miller, G. 2013. Estimating the direct and indirect water use of tourism in the eastern Mediterranean. Journal of Environmental Management, 114, 548-556.

Hardy, A. 2005. Using Grounded Theory to Explore Stakeholder Perceptions of Tourism. Journal of Tourism and Cultural Change, 3(2), 108-133.

Hillary, R. 2004. Environmental management systems and the smaller enterprise. Journal of Cleaner Production, 12(6), 561-569.

Idescat - Statistical Institute of Catalonia. 2016. Institut d'Estadística de Catalunya, Generalitat de Catalunya, Barcelona, Spain. Retrieved 15 March 2016, from http://www.idescat.cat/emex/

Instituto Nacional de Estadística. 2013. Cuenta Satélite del Turismo de España. Base 2008. Serie 2008-2012. Retrieved from http://www.ine.es/prensa/np829.pdf

Kasim, A. 2009. Managerial attitudes towards environmental management among small and medium hotels in Kuala Lumpur. Journal of Sustainable Tourism, 17(6), 709-725.

Kelly, J., \& Williams, P. 2007. Tourism destination water management strategies: An eco-efficiency modelling approach. Leisure/Loisir, 31(2), 427-452.

Kensbock, S., \& Jennings, G. 2011. Pursuing: A Grounded Theory of Tourism Entrepreneurs' Understanding and Praxis of Sustainable Tourism. Asia Pacific Journal of Tourism Research, 16(5), 489-504.

Kent, M., Newnham, R., \& Essex, S. 2002. Tourism and sustainable water supply in Mallorca: a geographical analysis. Applied Geography, 22(4), 351-374.

Kirk, D. 1995. Environmental management in hotels. International Journal of Contemporary Hospitality Management, 7(6), 3-8. 
Le, Y., Hollenhorst, S., Harris, C., McLaughlin, W., \& Shook, S. 2006. Environmental management. A Study of Vietnamese Hotels. Annals of Tourism Research, 33(2), 545-567.

Lee, J.-S., Hsu, L.-T. (Jane), Han, H., \& Kim, Y. 2010. Understanding how consumers view green hotels: how a hotel's green image can influence behavioural intentions. Journal of Sustainable Tourism, 18(7), 901-914.

March, H. 2015. Taming, controlling and metabolizing flows: Water and the urbanization process of Barcelona and Madrid (1850-2012). European Urban and Regional Studies, 22(4), 350-367.

Martin, D., \& Woodside, A. G. 2008. Grounded Theory of International Tourism Behavior. Journal of Travel \& Tourism Marketing, 24(4), 245-258.

McLennan, C.-L. J., Becken, S., \& Stinson, K. 2014. A Water-Use Model For The Tourism Industry In The Asia-Pacific Region: The Impact Of Water-Saving Measures On Water Use. Journal of Hospitality \& Tourism Research, 109634801455086.

Mensah, I. 2006. Environmental management practices among hotels in the greater Accra region. International Journal of Hospitality Management, 25(3), 414-431.

Miles, M. P., \& Covin, J. G. 2000. Environmental marketing: A source of reputational, competitive, and financial advantage. Journal of Business Ethics, 23(3), 299-311.

Millar, M., Mayer, K. J., \& Baloglu, S. 2012. Importance of Green Hotel Attributes to Business and Leisure Travelers. Journal of Hospitality Marketing \& Management, 21(4), 395-413.

Molina-Azorín, J. F., Claver-Cortés, E., Pereira-Moliner, J., \& Tarí, J. J. 2009. Environmental practices and firm performance: an empirical analysis in the Spanish hotel industry. Journal of Cleaner Production, 17(5), 516-524.

Neuman, W. L. 2005. Social research methods: Quantitative and qualitative approaches. Boston, MA: Allyn and Bacon.

Nicolau, J. L. 2008. Corporate Social Responsibility: Worth-Creating Activities. Annals of Tourism Research, 35(4), 990-1006.

Park, J., Jeong Kim, H., \& McCleary, K. W. 2014. The Impact of Top Management's Environmental Attitudes on Hotel Companies' Environmental Management. Journal of Hospitality \& Tourism Research, 38(1), 95-115.

Razumova, M., Ibáñez, J. L., \& Palmer, J. R.-M. 2015. Drivers of environmental innovation in Majorcan hotels. Journal of Sustainable Tourism, 23(10), 1529-1549.

Revilla, G., Dodd, T. H., \& Hoover, L. C. 2001. Environmental tactics used by hotel companies in Mexico. International Journal of Hospitality \& Tourism Administration, 1(3-4), 111-127.

Ribas, A., Calbó, J., Llausàs, A., \& Lopez-Bustins, J. A. 2010. Climate change at the local scale: trends, impacts and adaptations in a Northwestern Mediterranean Region (Costa Brava, NE Iberian Peninsula). International Journal of Climate Change: Impacts and Responses, 2(1), 247-264.

Riley, R. W., \& Love, L. L. 2000. The state of qualitative tourism research. Annals of Tourism Research, $27(1), 164-187$.

Rivera, J. 2004. Institutional pressures and voluntary environmental behavior in developing countries: Evidence from the Costa Rican hotel industry. Society and Natural Resources, 17(9), 779-797.

Sampaio, A. R., Thomas, R., \& Font, X. 2012. Why are some engaged and not others? Explaining environmental engagement among small firms in tourism. International Journal of Tourism Research, 14(3), 235-249.

Styles, D., Schoenberger, H., \& Galvez-Martos, J. L. 2015. Water management in the European hospitality sector: Best practice, performance benchmarks and improvement potential. Tourism Management, 46, 187-202.

Tzschentke, N. A., Kirk, D., \& Lynch, P. A. 2008. Going green: Decisional factors in small hospitality operations. International Journal of Hospitality Management, 27(1), 126-133.

Wei, S., \& Ruys, H. 1999. Managers' Perceptions of Environmental Issues in Australian Hotels. Australian Journal of Environmental Management, 6(2), 78-85.

Wheeler, D. 1995. Majorca's water shortages arouse Spanish passions. Geography: Journal of the Geographical Association, 80(3), 283.

Recibido:

$18 / 07 / 2018$

Reenviado:

$28 / 08 / 2019$

Aceptado:

$10 / 09 / 2019$

Sometido a evaluación por pares anónimos 